\title{
Post-splenectomy infections in chronic schistosomiasis as a consequence of bacterial translocation
}

\author{
Kedma de Magalhães Lima[1], Melissa Negro-Dellacqua ${ }^{[1]}$, \\ Victor Emmanuell Fernandes Apolônio dos Santos ${ }^{[1]}$ \\ and Célia Maria Machado Barbosa de Castro[2]
}

[1]. Colegiado de Enfermagem, Universidade Federal do Vale do São Francisco, Petrolina, Pernambuco, Brasil. [2]. Laboratório de Imunopatologia Keizo Asami, Departamento de Medicina Tropical, Universidade Federal de Pernambuco, Recife, Pernambuco, Brasil.

\begin{abstract}
Introduction: Bacterial translocation is the invasion of indigenous intestinal bacteria through the gut mucosa to normally sterile tissues and internal organs. Schistosomiasis may cause alterations in the immune system and damage to the intestines, portal system and mesenteric lymph nodes. This study investigated bacterial translocation and alterations in the intestinal microbiota and mucosa in schistosomiasis and splenectomized mice. Methods: Forty female 35-day-old Swiss Webster mice were divided into the following four groups with 10 animals each: schistosomotic (ESF), splenectomized schistosomotic (ESEF), splenectomized (EF) and control (CF). Infection was achieved by introduction of 50 Schistosoma mansoni (SLM) cercariae through the skin. At 125 days after birth, half of the parasitized and unparasitized mice were subjected to splenectomy. Body weights were recorded for one week after splenectomy; then, the mice were euthanized to study bacterial translocation, microbiota composition and intestinal morphometry. Results: We observed significant reductions in the weight increases in the EF, ESF and ESEF groups. There were increases of at least 1,000 CFU of intestinal microbiota bacteria in these groups compared with the CF. The EF, ESF and ESEF mice showed decreases in the heights and areas of villi and the total villus areas (perimeter). We observed frequent co-infections with various bacterial genera. Conclusions: The ESEF mice showed a higher degree of sepsis. This finding may be associated with a reduction in the immune response associated with the absence of the spleen and a reduction in nutritional absorption strengthened by both of these factors (Schistosoma infection and splenectomy).
\end{abstract}

Keywords: Schistosomiasis. Splenectomy. Bacterial translocation. Intestinal morphometry. Mesenteric lymph nodes.

\section{INTRODUCTION}

Bacterial translocation is the migration of bacteria from the intestinal lumen to the mesenteric lymph nodes or other extraintestinal sites ${ }^{(1)}$. Translocation physiology depends on the barrier effect of the intestinal mucosa and components of the cellular and humoral immune responses ${ }^{(2)}$. Enterococci and streptococci species, which are members of the Enterobacteriaceae family, very efficiently translocate to the mesenteric lymph nodes. These intestinal microorganisms are frequently associated with infections in immunodeficient individuals and can even translocate through histologically normal intestinal mucosa ${ }^{(3)}$.

Immunodepression associated with schistosomiasis in experimental models has been the focus of several studies ${ }^{(4)(5)(6)}$. During chronic schistosomiasis, intestinal blood flow is damaged

Corresponding author: Dra. Kedma de Magalhães Lima. Colegiado de Enfermagem/UNIVASF. Av. José de Sá Maniçoba s/n, Centro, 56304-205 Petrolina, Pernambuco, Brasil.

Phone: 5587 2101-6859

e-mail: kedma.magalhaes@univasf.edu.br; melissanegroluciano@gmail.com Received 13 March 2015

Accepted 4 May 2015 as a consequence of the traumatic, irritant and exfoliative actions of adult parasites feeding on blood and obstructing blood vessels. The spiky eggs of Schistosoma mansoni cause damage as they pass through the intestinal mucosa to be expelled in feces. A portion of these eggs are retained in the mucosa, causing chronic granulomatous inflammation ${ }^{(7)}$. Ferraz et al.$^{\left({ }^{(}\right)}$have described the presence of aerobic bacteria in the mesenteric lymph nodes of patients affected by chronic mansonic schistosomiasis. According to these authors, the presence of bacteria in the lymph nodes may be a consequence of bacterial translocation and may ease the development of post-operational infections.

Because one function of the spleen is immunoglobulin $\mathrm{M}$ (IgM) production, a reduction in this immunoglobulin might occur after splenectomy. The absence of the spleen might be postulated to ease bacterial translocation and sepsis in schistosomotic patients. However, several studies have reported that the IgM level remains high, even after partial or total splenectomy ${ }^{(9)}$ (10) (11). This finding might help to explain the reduction in the infection rate that has been reported in splenectomized schistosomotic patients $^{(12)(13)}$.

Some studies have reported a lack of severe sepsis in postoperative patients, even when schistosomiasis is associated with insufficient nourishment ${ }^{(14)}$. During chronic disease, IgM mediates the action of eosinophilic granular cells 
on Schistosoma and its egg antigens ${ }^{(15)}$. Thus, there is a direct correlation between the IgM concentration and the severity of schistosomiasis ${ }^{(16)}$. In contrast, a decline in the IgM level after total splenectomy has been documented in cases of trauma ${ }^{(11)(17)}$.

Petroianu and Antunes ${ }^{(12)}$ have described increases in the IgM and IgA levels in schistosomotic patients who have received subtotal and total splenectomy; thus, immunity seems to be preserved, even in the absence of a spleen. However, other studies have indicated that bacterial infections associated with schistosomiasis cause sepsis and pre-operational or post-surgical bacteremia $^{(5)(8)(18)}$. The results of these studies are contradictory; therefore, it is of fundamental importance to perform detailed experimental surveys without biasing factors. The primary goal of this study was to describe bacterial translocation in mice chronically infected with $S$. mansoni and to investigate the importance of splenectomy, weight variations, the intestinal microbiota, and duodenum morphometry in this process.

\section{METHODS}

\section{Animals and formation of experimental groups}

We used 40 female 35-day-old Swiss Webster mice. The animals were obtained from and kept in the bioterium of the Immunopathology Laboratory Keizo Asami (LIKA-UFPE). The mice were divided into the following four groups: schistosomotic $(\mathrm{ESF}=10$ mice); schistosomotic splenectomized ( $\mathrm{ESEF}=10$ mice); splenectomized ( $\mathrm{EF}=10$ mice) and control $(\mathrm{CF}=10$ mice) .

We infected the animals through the skin with 50 cercariae of S. mansoni (São Lourenço da Mata strain) after passage in the snail Biomphalaria glabrata.

We used 40 female mice aged 35 days. Half of these animals $(\mathrm{n}=20)$ were infected with $S$. mansoni, and the remainder formed the unparasitized group. Ten mice from each group were subjected to splenectomy at 90 days after exposure to the metacercariae (125 days after birth). One week after surgery (on the $97^{\text {th }}$ day after exposure to the parasites), all animals were euthanized as described below. In this study, we evaluated clinical samples at 14 weeks after infection because chronic schistosomiasis has been reported to begin at the $12^{\text {th }}$ week after contact with the cercariae ${ }^{(19)(20)}$.

\section{Splenectomy}

The mice were anesthetized with $2 \%$ xylazine chlorhydrate $(10 \mathrm{mg} / \mathrm{kg})$ and $10 \%$ ketamine chlorhydrate $(115 \mathrm{mg} / \mathrm{kg})$ according to Hall et al. ${ }^{(21)}$. The mice were kept alive after surgery. All mice were euthanized at seven days after surgery.

Animals who died during surgery were excluded from the experiment and replaced with new animals.

\section{Analysis of body weight and parasite load}

The evolution of body weight was recorded over the seven days after splenectomy. The animals were weighed using an electronic balance (Marte, model 1001, Brazil, capacity of $1,610.00$ grams, sensitivity of $0.1 \mathrm{~g}$ ). The weight of each animal was individually recorded.
Parasitological examination was performed using a fecal sample, according to the method of Kato-Katz ${ }^{(22)}$. The first sampling was performed at 45 days after exposure to the cercariae to confirm infection and to quantify the number of eggs per gram of feces prior to performing splenectomy. A successive sample was collected at 97 days after infection prior to euthanasia to study the pattern of egg laying after splenectomy. After recovery of biological samples, worms were collected as described by Yolles et al ${ }^{(23)}$. The collected worms were enumerated and sexed.

\section{Assessment of bacterial translocation in tissue samples}

After euthanasia, the mice were shaved on the ventral side of the abdomen and disinfected ( $1 \%$ iodopovidone) to avoid cross contamination of the samples or tubes with the external microbiota of the mice.

Peripheral blood $(0.5 \mathrm{ml})$ was collected by caudal puncture. A medial xifo-pubian incision was performed to collect portal blood $(0.5 \mathrm{ml})$, with a $13 \times 4.5$ needle and a $1 \mathrm{ml}$ disposable syringe. Mesenteric lymph node and liver fragments of approximately $0.03 \mathrm{~g}( \pm 0.01 \mathrm{~g})$ were collected, weighed, macerated and individually homogenized in sterile petri dishes and then placed into sterile tubes. Brain heart infusion broth (BHI; Bio Merieux Mercy L'Etoile, France) was added to all samples (1:5 weight to weight ratio), and they were then incubated at $37^{\circ} \mathrm{C}$ for 24 hours. After primary enrichment, the samples grown on BHI were transferred to bacteria-specific culture media (for both Gram-positive and Gram-negative bacteria). Blood agar, chocolate agar and MacConkey agar (Bio Merieux Mercy L'Etoile, France) were used to isolate enteric bacteria that translocated through the intestinal wall. Analysis of the plates was performed after 24 to 72 hours of incubation. Bacteria were identified using conventional biochemical tests and confirmed with automated equipment (VITEK 2 System ${ }^{\circledR}$ Bio Merieux Mercy L’Etoile, France).

\section{Intestinal microbiota analysis}

To quantify bacterial colonies per gram of feces (CFU/g), we used the method described by Naaber et al. ${ }^{(24)}$ and $\mathrm{Bisso}^{(25)}$. Fecal samples $(800 \mathrm{mg}$ ) were diluted in a sterile $\mathrm{NaCl}$ physiologic solution (1/10). After mechanical homogenization, a $10^{-1}$ dilution was obtained. We performed serial dilutions of this solution up to $10^{-6}$. A total of $0.1 \mathrm{ml}$ of each dilution was poured onto chromogenic agar (Agar CPS ID ${ }^{\circledR}$ Bio Merieux Mercy L'Etoile, France). The samples were distributed over the agar, and the plates were incubated for 24 hours at $37^{\circ} \mathrm{C}$. Bacteria were identified according to colony shape, biochemical features and microscopic features. The calculation of CFU was performed by multiplying the number of colonies on the agar plate by ten and by the serial dilution. The results were expressed as CFU of bacteria per gram of feces.

\section{Morphometric analysis of duodenal mucosa}

Fragments of the medial portion of the small intestine were collected from all animals by sagittal cuts, fixed in 10\% PBSbuffered formaldehyde and processed for inclusion in paraffin. 
From these materials, we obtained $5 \mu \mathrm{m}$ thick slices and stained them with hematoxylin-eosin. For morphometric analysis, we assessed the average heights and areas of the villi and the total mucosal surfaces (perimeter). A blinded examiner captured images from 5 random fields of the histological samples from each animal (total area of the field: $12,234 \mu \mathrm{m}^{2}$ and total visualized area: $\left.61,170 \mu \mathrm{m}^{2}\right)$. Morphometric analysis of the intestinal mucosa was performed with Image J software ${ }^{(26)}$. We determined the heights of the villi and depths of the crypts. Villus height was measured from the basal region of the villus at the superior portion of the crypt to its apex. Crypt depth was measured from the base to the transition region between the crypt and villus. The obtained values were expressed as the number of pixels.

\section{Data presentation and analysis}

Statistical Package for the Social Sciences (SPSS, Inc., Chicago, IL, USA) was used for data analysis and processing. During the descriptive phase, the arithmetic mean was calculated after exclusion of extreme values, and confidence intervals and standard deviations were used to identify the minimum and maximum values. During the analytical phase, the arithmetic means of the variables of the two groups were compared using Student's t-test for independent samples. The Friedman test was used to assess differences among the weights of the mice according to the day of measurement and group. Differences among the average weights of the mice in the different study groups on the separate days of measurement were assessed by two-by-two multiple comparison tests. In all situations, a maximum error probability of $5 \%$ was considered for rejection of the null hypothesis.

\section{Ethical considerations}

This study was approved by the ethical committee on animal experimentation of the Center for Biological Sciences of the Federal University of the State of Pernambuco (Brazil).

\section{RESULTS}

\section{Parasitological analysis}

There was no significant difference in the average amount of adult worms collected in the schistosomotic mice between the ESF and ESEF groups ( $p$-value $>0.05$ ). Male worms were more abundant than females ( $\mathrm{p}$-value $<0.01$ ).
As shows Table 1, in the ESF and ESEF mice, the number of eggs per gram of feces was higher on the $45^{\text {th }}$ day compared with that on the $97^{\text {th }}$ day after infection ( $p$-value $<0.01$ ).

\section{Analysis of weight}

As presented in Figure 1, we observed increases in the weights of both the CF and ESF mice (p-value $<0.01$ and $\mathrm{p}$-value $<0.03$, respectively). In contrast, the EF and ESEF mice showed decreases in weight ( $\mathrm{p}$-value $<0.01$ ).

We observed significant differences in weight gain on the different days of measurement among the different groups studied ( $p$-value $<0.010$ ).

\section{Study of enteric microbiota}

Table 2 presents quantitative analysis of the enteric samples obtained from the mice in the different groups studied. All of the treated mice presented growth of at least $10^{3} \mathrm{CFU}$ of general enteric bacteria (both Gram-negative and Gram-positive species) compared with the CF mice.

Mice in the ESF and ESEF groups showed similar numbers of bacterial colonies. Significant differences were only detected for Staphylococcus aureus, Enterococcus faecalis and Klebsiella pneumoniae.

\section{Histomorphometric analysis of the duodenum}

Macroscopic analysis of the intestines of the schistosomotic mice showed hypertrophy and fibrosis of the intestinal loops. Histologic analysis revealed schistosomotic granulomas that were primarily productive and evolving to fibrotic cicatrization of the lamina propria and sub-mucosa. Granulomas were isolated or in coalescence and were composed of macrophages and lymphocytes very close to the egg or its vestiges and few eosinophils, resulting in a shift of the villi to the intraluminal space. Histopathological findings were chosen as the exclusion criteria for morphometric analyses because such abnormalities could cause apparent increases in the height and area of the villi. The control group showed normal histological and gross anatomical appearances.

The average total villus areas were as follows: 532.0 (102.9) $\mu \mathrm{m}$ for the CF mice; 509.3 (79.4) $\mu \mathrm{m}$ for the EF mice; $238.2(88.8) \mu \mathrm{m}$ for the ESF mice and $217.3(68.1) \mu \mathrm{m}$ for the ESEF mice. Based on these results, we observed significant differences in the total villus areas among the different groups (p-value $<0.01)$.

TABLE 1 - Number of parasites in Schistosoma mansoni-infected mice, splenectomized mice and non-splenectomized control mice.

\begin{tabular}{|c|c|c|c|c|c|c|c|}
\hline \multirow[b]{2}{*}{ Schistosomotic } & \multicolumn{7}{|c|}{ Parasitological parameters } \\
\hline & males & females & total & p-value* & 45 & 97 & p-value* \\
\hline $\operatorname{ESEF}(n=10)$ & $12.0(3.36)$ & $7.6(1.34)$ & $19.6(4.70)$ & $<0.01$ & $189.0(4.8)$ & $138.5(7.3)$ & $<0.05$ \\
\hline $\operatorname{ESF}(n=10)$ & $10.8(1.6)$ & $8.0(0.9)$ & $18.8(1.5)$ & $<0.01$ & $149.0(8.2)$ & $192.3(5.5)$ & $<0.05$ \\
\hline
\end{tabular}

ESEF: schistosomotic splenectomized; ESF: schistosomotic non-splenectomized. *Mann-Whitney test. Quantification of parasites in splenectomized and not splenectomized mice. Note: The values are expressed as the average \pm standard deviation. 

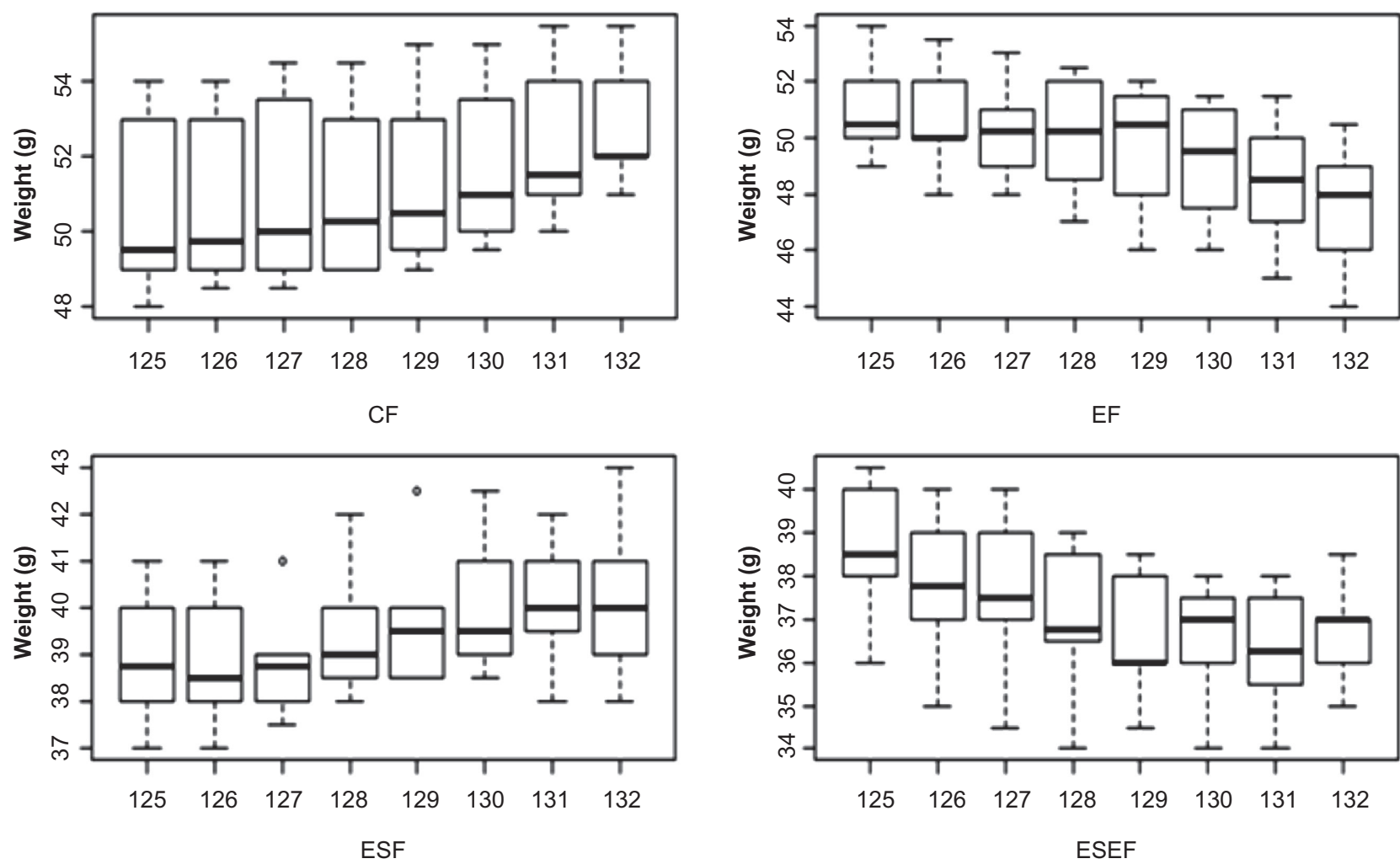

FIGURE 1 - Boxplot of the evolution of mouse weights in the different groups at different time points (expressed as days). CF: control; EF: splenectomized; ESF: schistosomotic non-splenectomized; ESEF: schistosomotic splenectomized.

TABLE $2-\log _{10} \mathrm{CFU} / \mathrm{g}$ of bacteria isolated from the different groups of mice.

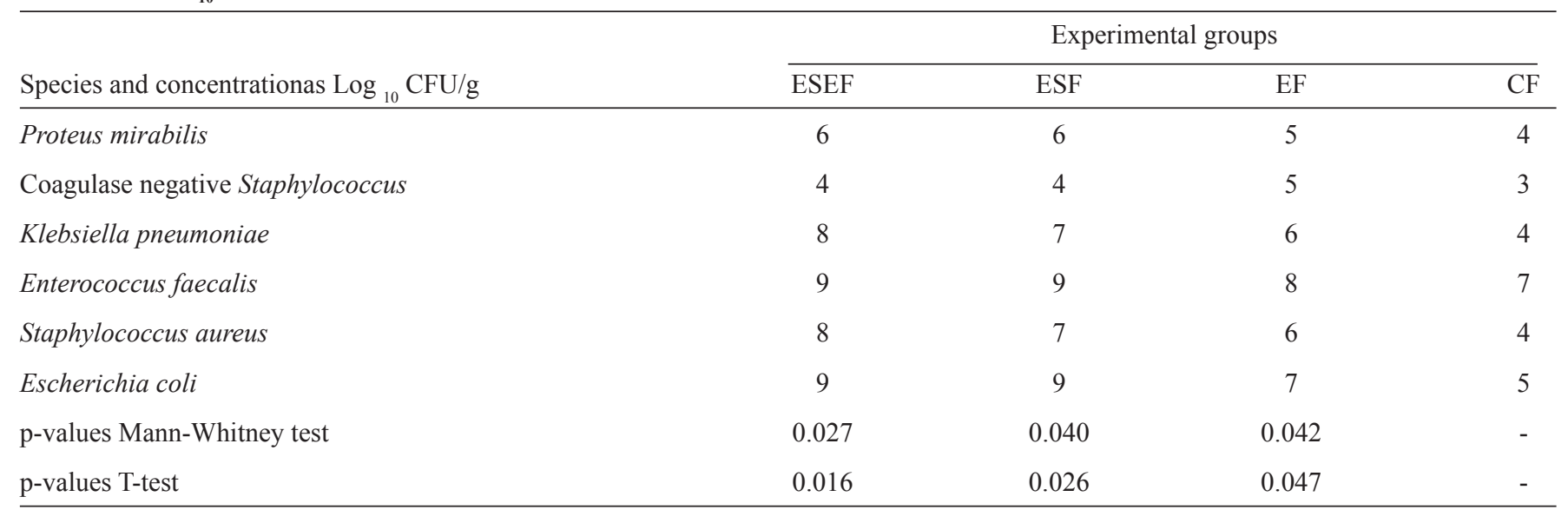

CFU/g: colony forming units; ESEF: schistosomotic splenectomized; ESF: schistosomotic non-splenectomized; EF: splenectomized; CF: control.

The villus heights were as follows: $123.3(12.2) \mu \mathrm{m}$ for the CF mice, 112.4 (5.3) $\mu \mathrm{m}$ for the EF mice, 93.9 (7.9) $\mu \mathrm{m}$ for the ESF mice and $90.1(8.4) \mu \mathrm{m}$ for the ESEF mice. The villus heights were significantly among between the different groups (p-value $<0.01)$.
The average villus areas were as follows: $3.4(0.1) \mu \mathrm{m}$ for the CF group, $3(0.1) \mu \mathrm{m}$ for the EF group, $2.4(0.2) \mu \mathrm{m}$ for the ESF group and $2.3(0.1) \mu \mathrm{m}$ for the ESEF group. The average areas were significantly different among the different groups (p-value $<0.01$ ). 


\section{Bacterial translocation}

We observed bacterial translocation to the mesenteric lymph nodes in all groups. The ESEF animals presented the highest prevalence of translocation to the mesenteric lymph nodes. The CF mice presented only translocation of Escherichia coli. We also observed translocation to the portal blood, liver and peripheral blood in all groups except for the $\mathrm{CF}$ group.

One hundred percent of the bacterial cultures from schistosomotic mouse mesenteric lymph node samples showed the presence of bacteria. From these samples, we isolated $S$. aureus (6), S. aureus associated with E. faecalis (1), or E. faecalis alone (1). A total of $60 \%$ of the mice presented bacterial contamination of the portal blood with $S$. aureus (4) or E. coli (2). A total of $50 \%$ showed bacterial translocation of only $S$. aureus to the liver (5), and 30\% exhibited translocation of only S. aureus to the peripheral blood (3).

The bacterial cultures from the ESEF animals showed $100 \%$ translocation to the mesenteric lymph nodes. From these samples, we isolated E. coli (3), Proteus mirabilis (2), E. faecalis (1), Klebsiella pneumoniae (1), S. aureus (1), E. faecalis and $S$. aureus (1). A total of $70 \%$ of the mice presented contamination of the portal blood with E. coli (2), P. mirabilis (2), S. aureus (2) or E. faecalis (1). Half of the EF animals presented bacterial translocation of E. coli (2), S. aureus (2) or E. faecalis (1) to the liver. Only two animals presented translocation to the peripheral blood, with E. faecalis in one case and the $S$. aureus in the other.

A total of $100 \%$ of the bacterial cultures from samples isolated from the ESEF mice showed translocation to the mesenteric lymph nodes. From these samples, we isolated $S$. aureus and E. faecalis (2), E. coli and coagulase-negative Staphylococci (1), coagulase-negative Staphylococci and P. mirabilis (1), E. faecalis and E. coli (1), E. faecalis (1) or $K$. pneumoniae (1). All mice presented bacterial translocation to the portal blood of S. aureus (3), E. coli (2), E. faecalis (1), $K$. pneumoniae (1), Providencia rettgeri (1), negative-coagulase Staphylococci with P. mirabilis (1) or S. aureus with P. mirabilis (1). A total of $90 \%$ of the ESEF mice also showed translocation of bacteria to the liver, including S. aureus (4), E. coli (2), K. pneumoniae (1), P. rettgeri (1), or negative-coagulase Staphylococci and P. mirabilis (1). A total of $60 \%$ of the mice showed translocation of S. aureus (3), E. coli (1), K. pneumoniae (1) or coagulase-negative Staphylococci associated with P. mirabilis (1) to the peripheral blood.

We did not observe growth of anaerobic microorganisms or fungi.

\section{DIscussion}

In the present study, the amounts of adult worms isolated from the venous portal system and mesenteric veins of the ESF and ESEF mice were roughly the same. Male worms were more common than females in both groups, in agreement with the results of a previous study by Boissier et al. ${ }^{(27)}$. These authors described the development of different genotypes of this parasite in permissive hosts that induced strong competition among females, and as a consequence, an increase in the number of males. In contrast, Martinez et al. ${ }^{(28)}$ reported the recovery of similar proportions of males and females after infection caused by different Brazilian strains. Splenectomy did not interfere with worm collection or the sex ratio of the schistosomotic animals.

The development of the disease caused by $S$. mansoni has been described to begin with low egg laying, which increases gradually between 45 and 72 days and later decreases at three weeks after the incubation period ${ }^{(29)(30)}$. In this work, the number of eggs per gram of feces in the schistosomotic animals with or without splenectomy was higher on the $45^{\text {th }}$ compared with the $97^{\text {th }}$ day of infection. According to the literature, this period corresponds with the onset of chronic infection in mice ${ }^{(29)(30)}$.

All of the animals in the treatment groups showed reductions in weight gain compared with those in the CF group. Thus, chronic schistosomiasis and the initial period after splenectomy were associated with a reduction in weight gain. This finding was even more evident when schistosomiasis and splenectomy were considered together. The reduction in weight gain after splenectomy might be influenced by parasite activity, weakness after surgery and difficulty in feeding. Indeed, the feeding difficulties experienced by the animals in the ESEF group affected their nutritional statuses and immune responses.

Some functions of the intestinal microbiota (i.e., resistance to colonization, modulation of the immune system and provision of nutrition) are extremely relevant for the host ${ }^{(31)}$. The importance of the digestive system for the handling and treatment of infected patients has been increasingly reported over the last few years. Researchers have proposed that the small and large intestines may be involved in the hypermetabolism of sepsis, systemic inflammatory response syndrome and multiple organ and system disorders ${ }^{(32)}$. In general terms, under physiological conditions, resident microorganisms of the digestive system are innocuous or beneficial to the host in their normal locations. Under specific conditions, the same resident microbes may cause disease. Moreover, resident bacteria are usually limited to the lumen of the intestinal tract. If they enter into other systems (i.e., blood or other tissues), they may cause disease ${ }^{(33)(34)}$.

Based on the quantification of bacteria found in feces extracted from the medial region of the small intestine, our data support the hypothesis that both chronic schistosomiasis and splenectomy modify mouse intestinal flora. A breakdown of the equilibrium of the autochthonous microbial population contributes to the selective overgrowth of some species, which may promote the translocation process ${ }^{(35)(36)}$. Immunomodulation might explain the alterations in microbial populations that occur during schistosomiasis. In the case of splenectomy, the altered microbiota may be explained both by a change in nutritional status and by hypertrophy of the villi.

Hepatic fibrosis and portal hypertension are typical of the hepatosplenic form of schistosomiasis. Propagation of these alterations may change the intestinal mucosa and cause reductions in villus heights ${ }^{(37)}$, as described above. Moreover, we also observed alterations in the height and area of villi in the splenectomized mice. To the best of our knowledge, there is no report in the literature of alterations in the intestinal mucosa 
after splenectomy. Importantly, there are few studies of the consequences of the absence of a spleen on lymphoid tissues and organs. Spleen removal has been demonstrated to affect immune function in a systemic manner, while concurrently affecting distinct immune functions in different compartments of organisms ${ }^{(12)}$. Nonetheless, splenectomized individuals can survive despite limitations and a higher risk of infection. In the present study, we failed to detect alterations in duodenal mucosal morphometry between the EF and ESEF animals.

Several studies using animals have shown that translocation is a multifactorial phenomenon resulting from the breakdown of the equilibrium of normal microbiota and the overgrowth of specific bacterial species. Weaknesses in immunity or damage to the intestinal wall may (either alone or in conjunction) facilitate the passage of bacteria ${ }^{(35)(36)(38)}$. Chronic schistosomiasis, splenectomy associated with weight reduction and alterations in immune responses and the duodenal mucosa resulting from infection may have contributed to the increase in the intestinal microbiota diversity and the consequent increase in bacterial translocation observed in this study. However, further studies are required to explain our results.

Bacterial cultures from extra-intestinal sites are assessed to study bacterial translocation. Bacteria from homogenized mesenteric lymph nodes, liver, spleen, and portal and peripheral venous blood and detection of endotoxins from portal and peripheral venous blood are the most common examples described in the literature ${ }^{(35)(39)(40)}$. In our experience, we observed bacterial translocation to mesenteric lymph nodes in the CF group, but no other organ was affected.

According to our results, bacterial translocation to the mesenteric lymph nodes, portal blood, liver and peripheral blood occurred in the splenectomized mice. Some of these mice developed sepsis. We observed two different genera of bacteria in the mesenteric lymph nodes, with a prevalence of Gram-positive bacterial infections. The splenectomized mice did not show adequate responses to bacterial antigens ${ }^{(40)}$. The spleen has a higher capacity for the phagocytosis of microorganisms than the liver. In patients without a spleen, the absence of this organ is counterbalanced not by the splenic portion of the phagocytic mononuclear system but by the reduced production of antibodies. IgG activity and IgM production decrease under these conditions ${ }^{(41)(42)}$.

Infection by $S$. mansoni is more severe in mice than in humans. Thus, mice are a good experimental model for this parasitosis ${ }^{(43)}$. In the present work, some of the splenectomized infected mice showed bacterial translocation to the mesenteric lymph nodes, portal blood, liver and peripheral blood, with accompanying sepsis. This finding might be associated with changes caused by chronic infection (i.e., alterations to the normal microbiota, intestinal villi and immune system). Our data are in support of the findings of other studies of bacterial translocation associated with immunodeficiency and alterations in villi caused by $S$. mansoni in vertebrate hosts ${ }^{(8)(34)}$.

The ESEF mice showed higher rates of bacterial translocation compared with the ESF animals, even if these two groups of animals showed no differences in morphometric or parasitological parameters on the $45^{\text {th }}$ and $97^{\text {th }}$ days of infection.
Finally, although some studies have reported no increase in sepsis resulting from schistosomiasis in association with splenectomy ${ }^{(12)(14)}$, we observed a higher prevalence of bacterial translocation to the peripheral blood in the schistosomotic and splenectomized mice compared with those that were only splenectomized or only schistosomotic. This finding may be associated with a weakened immune response due to the absence of the spleen and deterioration of the nutritional status fostered by both factors (Schistosoma infection and splenectomy). Further studies must be performed focusing on bacterial translocation in schistosomiasis associated with splenectomy to confirm and expand upon our results. Future studies will be important to provide more comprehensive data that may help to improve the treatment of patients with chronic schistosomiasis and secondary recurrent infections associated with intestinal bacterial species after splenectomy. Our findings provide evidence of bacterial translocation from the intestine to systemic circulation. Thus, critical illness may create a hostile environment in the gut and alter the intestinal microflora, thereby fostering the growth of pathogens by promoting bacterial translocation.

\section{CONFLICT OF INTEREST}

The authors declare that there is no conflict of interest.

\section{REFERENCES}

1. Berg AD, Garlington AW. Translocation of certain indigenous bacteria from the gastrointestinal tract to the mesenteric limph nodes and the other organs in a gnotobiotic mouse model. Infect Immun 1979; 23:403-411.

2. Wiest R, Rath HC. Bacterial translocation in the gut. Best Pract Res Clin Gastroenterol 2003; 17:397-425.

3. Wells RA, Hummel JL, De Koven A, Zipursky A, Kirby M, Dubé I, et al. New variant translocation in acute promyelocytic leukaemia: molecular characterization and clinical correlation. Leukemia 1996; 10:735-740.

4. Araújo FG, Coelho PMZ, Pereira LH, Pellegrino J. Schistosoma mansoni: impairment of the cell-mediated immune response in mice. Clin Exp Immunol 1977; 28:289-291.

5. Ferraz AAB, Santos Junior MA, Mathias CA, Magalhães M, Barcelar T, Ferraz EM. Modelo de peritonite experimental em camundongos esquistossomóticos. Acta Cir Bras 1993; 8:28-31.

6. Elias D, Akuffo H, Thors C, Pawlowsk A, Britton S. Low dose chronic Schistosoma mansoni infection increases susceptibility to Mycobacterium bovis BCG infection in mice. Clin Exp Immunol 2005; 139:398-404.

7. Katz N, Almeida K. Esquistossomose, xistosa, barriga d'água. Cienc Cult 2003; 55:38-43.

8. Ferraz AAB, Campos JM, Araújo Júnior JGC, Albuquerque AC, Ferraz EM. Gut Bacterial Translocation and Postoperative Infections: A prospective study in schistosomotic patients. Surg Infect 2005; 6:197-201.

9. Curiel M, Chaves J, Torrealba JW. Immunoglobulin levels in schistosomiasis. Rev Inst Med Trop São Paulo 1974; 14:384-387.

10. Camus D, Carlier Y, Capron M, Bina JC, Figueiredo JFM, Prata A, et al. Immunological studies in human schistosomiasis. Am J Trop Med Hyg 1977; 26:482-490. 
11. Guerra LCM, Neto JE, Miranda PJC, Silveira MJC, Brandt CT, Kelner S. Variações dos valores séricos de IgG, IgA, IgM, C3 e $\mathrm{C} 4$ após esplenectomia em esquistossomóticos hepatoesplênicos. Acta Cir Bras 1991; 6:123-126.

12. Petroianu A, Antunes LJ. Aspectos imunológicos da esquistossomose mansoni hepatoesplênica após cirurgia terapêutica. Rev Bras Hematol Hemoter 2003; 25:149-154.

13. Petroianu A. Subtotal splenectomy for treatment of retarded growth and sexual development associated with splenomegaly. Minerva Chir 2003; 57:413-414.

14. Resende V, Petroianu A, Junior WCT. Autotransplantation for treatment of severe splenic lesions. Emereg Radiol 2002; 9:208-212.

15. Butterworth A, Dunne D, Fulford A, Capron M, Khalife J, Capron A, et al. Immunity in human schistosomiasis mansoni: crossreactive $\operatorname{IgM}$ and $\operatorname{IgG} 2$ anticarbohydrate antibodies block the expression of immunity. Biochimie 1988; 70:1053-1063.

16. Dunne DW, Fulford AJC, Butterworth AE, Koech D, Ouma JH. Human antibody responses to Schistosoma mansoni. Mem Inst Oswaldo Cruz 1987; 82:101-104.

17. Schumacher MJ. Serum immunoglobulin and transferrin levels after childhood splenectomy. Arch Dis Child 1970; 45:114-117.

18. Nishioka AS, Ferreira MS, Burgarelli MKN. Serratia marcenscens bacteremia associated with schistosomiasis mansoni. Rev Soc Bras Med Trop 1992; 25:191-193.

19. Fallon PG. Immunopathology of schistosomiasis: a cautionary tale of mice and men. Immunol. Today 2000; 21:29-35.

20. Pearce EJ, Macdonald AS. The immunobiology of schistosomiasis. Nat Ver Immunol 2002; 2:499-511.

21. Hall LW, Clarke KW. Veterinary Anesthesia. $8^{\text {th }}$ ed. London: Bailliére Tindal; 2001.

22. Katz N, Chaves A, Pellegrino J. A simple device for quantitative stool thick-smear technique in schistosomiasis mansoni. Rev Inst Med Trop Sao Paulo 1972; 14:397-400.

23. Yolles TK, Moore DV, De Giusti DL, Ripson CA, Meleney HE. A technique for the perfusion of laboratory animals for the recovery of schistosomes. J Parasit 1947; 33:419-426.

24. Naaber P, Mikelsaar RH, Salminent S, Mikelsaar M. Bacterial translocation, intestinal microflora and morphological changes of intestinal mucosa in experimental models of Clostridium difficile infection. J Med Microbiol 1998; 47:591-598.

25. Bisso LM. Modelo Murino de inflamação intestinal crônica: Avaliação quantitativa da dinâmica da microbiota intestinal. 2008. 133 p. (Master's Dissertation). Programa de Pós graduação em Patologia. Universidade Federal Fluminense; 2008 Rio de Janeiro.

26. Rasband WS. Image J. Bethesda, Maryland, USA: National Institutes of Health; 2004. (Cited 2015 March). Available at: http:// rsb.info.nih.gov/ij/

27. Boissier J, Morand S, Moné H. A review of performance and pathogenecity of male and female Schistosoma mansoni during the life-cycle. Parasitology 1999; 119:447-454.

28. Martinez EM, Neves RH, Oliveira RMF, Machado-Silva JR, Rey L. Características biológicas e morfológicas de cepas brasileiras de
Schistosoma mansoni em Mus musculus. Rev Soc Bras Med Trop 2003; 36:557-564.

29. Barth LR, Fernandes APM, Rodrigues V. Oviposition by Schistosoma mansoni during in vitro cultivation. Rev Inst Med Trop São Paulo 1996; 38:423-426.

30. El-Ridi R, Ozaki T, Inaba T, Ito M, Kamiya M. Schistosoma mansoni oviposition in vitro reflects worm fecundity in vivo: individual-parasite age- and host-dependent variations. Int J Parasitol 1997; 27:381-387.

31. Franco de Moraes AC, Tande da Silva I, de Almeida Pititto BG, Ferreira SR. Microbiota intestinal e risco cardiometabólico: mecanismos e modulação dietética. Arq Bras Endocrinol Metab 2014:317-327.

32. Deitch EA, Kemper AC, Specian RD, Berg RD. A study of the relationships between bacterial translocation, gut origin sepsis and survival in a model of systemic inflammation. J Trauma 1992; 32:141-147.

33. Gorbach SL, Simon GL. Intestinal flora and digestory function. In: Johnson LR, editor. Physiology Gastrointestinal Tract. $2^{\text {th }}$ ed. New York: Raven Press: 1987, p. 1729-1747.

34. Barbosa FHF, Martins FS, Barbosa LPJL, Nicoli JR. Microbiota indígena do trato digestório. Rev Biol Ciênc da Terra 2010; 10:78-93.

35. Gencay C, Kilicoglu SS, Kismet K, Kilicoglu B, Erel S, Muratoglu $\mathrm{S}$, et al. Effect of honey on bacterial translocation and intestinal morphology in obstructive jaundice. World J Gastroenterol 2008; 14:3410-3415.

36. Siqueira LT, Ferraz AA, Campos JM, Lima Filho JL, Albuquerque MC, Lima Aires A, et al. Analysis of plasma citrulline and intestinal morphometry in mice with hepatosplenic schistosomiasis. Surg Infec 2010; 11:1-8.

37. Nikitenko VI, Stadnikov AA, Kopylov VA. Bacterial translocation from the gastrointestinal tract in healthy and injured rats. J Wound Care 2011; 20:114-122.

38. Çelik A, Aydemir S, Alkanat M, Habif S, Keskinoglu A, Erdener D. Hemorrhagic shock and bacterial translocation. J Appl Res 2005; 5:196-205.

39. Silva RM, Buzzutti FI, Siliano PR, Menchaca-Diaz JL, Siqueira AFRS, Koh IHJ. Bacterial translocation is dependent on bacterial plasmid-borne genetic determinants. Transplant. Proc 2002; 34:999-1000.

40. Amlot PL, Hayes AE. Impaired human antibody response to the thymus-independent antigen, DNP-Ficoll, after splenectomy. Implications for post-splenectomy infections. Lancet 1985; 1:1008-1011.

41. Cooney DR, Dearth JC, Swanson SE, Dewanjee MK, Telander RL. Relative merits of partial splenectomy, splenic reimplantation, and immunization in preventing postsplenectomy infection. Surgery 1979; 86:561-569.

42. Cunha BA. Infection in nonleukopenic compromised hosts (diabetes mellitus, sle, steroids, and asplenia) in critical care. Infect Crit Care 1998; 14:263-82.

43. Warren KS. The pathogenesis of "clay-pipe stem cirrhosis" in mice with chronic schistosomiasis mansoni, with a note on the longevity of the schistosomas. Am J Pathol 1966; 49:477-489. 